\title{
SOCIO-ECONOMIC IMPACT OF COVID-19 IN NIGERIA
}

Godfrey Ejiroghene Akpojotor ${ }^{1}$, Ndakara Ofudjaye ${ }^{2}$, Obi Calistar Kidochukwu ${ }^{3}$, Okinono Otega $^{4}$, Okonta Ifeanyi Patrick ${ }^{5}$, Morka Emmanuel ${ }^{6}$, Jonathan Maviano Abel ${ }^{7}$, Michael Ozioma Emmanuel ${ }^{8}$, Egboduku Wisdom Oghenevwogaga ${ }^{8}$, Okposo Ighomaro Newton ${ }^{7}$, Okolugbo Chinedu Benard ${ }^{9}$, Ogharanduku Theodora ${ }^{9,10}$, Okpara Nathaniel ${ }^{11}$, Odibo Ewomazino Oghenekome ${ }^{9}$, Ossiaugbo Ifeanyi Marcus ${ }^{7}$, Agbogidi Oghenerioborue Mary ${ }^{8,12}$, Avwioro Godwin ${ }^{13}$, Tonukari Nyerovwo ${ }^{1}$, Owhe-Ureghe Ubreye Benjamin ${ }^{6,14}$, Akpojotor Godfrey $^{11,15}$, Nmorsi Goddey Patrick ${ }^{9,16}$, and Egwunyenga Andy ${ }^{9,17}$

${ }^{1}$ Affiliation not available

${ }^{2}$ Department of Geography and regional Planning, Delta State University

${ }^{3}$ Department of Economics, Delta State University

${ }^{4}$ Department of Sociology and Psychology, Delta State University

${ }^{5}$ Department of Obstetrics and Gynaecology, Faculty of Clinical Medicine, College of Health Sciences

${ }^{6}$ Department of Microbiology, Delta State University

${ }^{7}$ Department of Mathematics, Delta State University

${ }^{8}$ Department of Botany, Delta State University

${ }^{9}$ Department of Animal and Environmental Biology, Delta State University

${ }^{10}$ Department of Infectious Disease Epidemiology, School of Hygiene and Tropical Medicine

${ }^{11}$ Department of Physics, Delta State University

${ }^{12}$ Centre for Plants Conservation and Utilization, Delta State University

${ }^{13}$ Department of Science Laboratory Technology, Delta State University

${ }^{14}$ Centre for Biotechnology Research, Delta State University

${ }^{15}$ Centre for Research and International Programmes, Delta State University

${ }^{16}$ Advanced Research Centre, Delta State University

${ }^{17}$ Vice Chancellor's Office, Delta State University

November 11, 2020

\section{Hosted file}

Socioeconomic and covid-19 Full Names-1.pdf available at https://authorea.com/users/369252/ articles/491406-socio-economic-impact-of-covid-19-in-nigeria 